\title{
Determinants of Leprosy Incidence in The Work Area of The Kebon Jeruk Health Center in 2019
}

\author{
${ }^{1}$ Rizky Aliyani Putri, ${ }^{2}$ Deasy Febriyanty \\ ${ }^{1}$ Student of Public Health Study Program, Esa Unggul University \\ ${ }^{2}$ Lecturer of Public Health Study Program, Esa Unggul University \\ Jl. North Arjuna No. 9, RT/RW 05/02 Duri Kepa Kebon Jeruk West Jakarta 11510 \\ E-mail: rzkalianiputri@gmail.com
}

\begin{abstract}
Leprosy or leprosy is an infectious disease caused by infection with the bacterium Mycobacterium leprae (M. leprae) which attacks various parts of the body including nerves and skin. Based on data obtained from the Kebon Jeruk Health Center, leprosy cases were still found, namely from 20165 cases, then there was a very significant increase in 2017 to 16 cases, in 2018 to 14 cases, and 2019 until April 7 cases were found. This study aims to determine the factors related to the incidence of leprosy in the working area of the Kebon Jeruk Public Health Center in 2019. This study used a case-control design with a sample size of 90 respondents. Sampling in this study used a simple random sampling technique for the case group and purposive sampling for the control group and analyzed with the chi-square test which was conducted from December 2019 to January 2020. In the results of this study, there were 30 respondents (33.3\%) who suffered from leprosy. There is a significant relationship between age ( $\rho=$ 000), personal hygiene $(\rho=0.000)$ with the incidence of leprosy. It is recommended that respondents maintain personal hygiene and improve a clean and healthy lifestyle (PHBS).
\end{abstract}

Keywords: Leprosy, Age, Gender, Personal Hygiene 


\section{INTRODUCTION}

Leprosy or leprosy is an infectious disease caused by infection with the bacterium Mycobacterium leprae (M. leprae) which attacks various parts of the body including nerves and skin. This disease is one of the chronic infectious diseases that causes very complex problems, the problems caused are not only from a medical perspective (the disease itself) but also has a psychosocial impact on the sufferer, even this disease creates a negative stigma in society which is still present and feared. This bacterium undergoes a long division process between 2-3 weeks, the survival of leprosy bacteria reaches 9 days outside the human body. Leprosy bacteria have an incubation period of 2-5 years and it can even take more than 5 years (Kemenkes RI, 2015).

The Indonesian Ministry of Health (2015) stated that leprosy is caused by a bacterium called Mycobacterium Leprae. Where this mycobacterium is an aerobic bacterium, does not form spores, rodshaped, surrounded by a waxy cell membrane that is characteristic of Mycobacterium species, measuring 1-8 micro long, 0.2-0.5 micron wide, usually in groups and some are scattered one-to-one. one lives in cells and is acid-fast (BTA) or gram-positive, not easily stained but if stained it is resistant to decolorization by acids or alcohols and is therefore called an 'acid-fast' bacillus. These germs are transmitted to humans through direct contact with sufferers (both of which must have microscopic and macroscopic lesions and prolonged and repeated contact) and through inhalation, 5 years. After five years, signs of a person suffering from leprosy begin to appear, among others, the skin experiences white, red patches, tingling sensations in the limbs so that they do not function properly. Poor case management can cause leprosy to become progressive, causing permanent damage to the skin, nerves, limbs, and eyes.

Bloom (1974), four factors affect the health status of the community, namely the environment, behavior, health services, and heredity. From that section and based on the disease, it is taken that the most influencing factor is the environmental factor and then the behavioral factor. An environment that has bad conditions can be a source of disease development, such as the physical environment, namely the disposal of garbage that is not clean and regular, the sanitation of the water used is dirty or smelly, the disposal of feces that is not in place and when viewed from behavioral factors, namely rarely changing bedding or bed linen behavior often sleep together with lepers, and also the behavior of often using the same clothes as lepers.

World Health Organization (2013), Indonesia ranks third in the world after India and Brazil, in 2013 Indonesia had 16,856 new cases of leprosy and 9.86\% of new cases of disability. However, due to the increased detection of active cases, more new cases were detected in Brazil, Indonesia, and Somalia (WHO, 2013). In 2018 showed that a total of 208,619 new cases of leprosy were reported in 2018 from 127 countries including all priority endemic countries, compared with 211,009 cases (representing a slight global decline of 1.2\%) in 2017. The registered global prevalence of the disease at the end of 2018 decreased by 8,501 cases from those reported at the end of 2017. But despite progress in some countries, 
there was an increase in cases of leprosy. The soaring number of new cases observed in several countries is due to active case detection campaigns, in particular the increase in contact screening, in addition to routine leprosy control activities that have influenced the trend in new case detection. (WHO, 2018).

Case detection in the Southeast Asia region reported $71 \%$ of all global cases: 2 countries India $(120,334$ cases) and Indonesia (17,017 cases) contributed 92\% of cases in this region. In the Americas region, Brazil continues to report a high case rate (28,665 cases) representing $93 \%$ of all cases in the region. Brazil, India, and Indonesia combined account for $79.6 \%$ of all new cases detected globally. From 159 countries and territories that provided data, 32 reported 0 cases, 47 reported 1-10 cases, 24 reported 11-100 cases, 41 reported 101-1000 cases and 15 reported more than 1000 cases, including Brazil, India, and Indonesia respectively. each reported more than 10,000 new cases. Data from national leprosy programs from 23 priority 1 countries accounted for 199,400 new cases, representing $96 \%$ of total cases worldwide. This number is comparable to the cases reported in 2017. The Indonesian Ministry of Health (2013) recorded 16,825 new cases of leprosy, with a rate of 6.82 per 1,000,000 population. This figure puts Indonesia in third place in the world with new cases the most leprosy after India (134,752 cases) and Brazil (33,303 cases).

Although Indonesia has achieved the elimination of leprosy in 2000 until now discovery of leprosy cases is still found in several areas. For this reason, the Indonesian Ministry of Health targets that all provinces can achieve leprosy elimination status by 2019. Currently, only 20 out of 34 provinces have successfully eliminated them. In 2016, the next target is the elimination of leprosy in Central Sulawesi and Aceh. In 2017, the target for leprosy elimination is in Southeast Sulawesi, East Java, and South Sulawesi. In 2018 the leprosy elimination target is in West Sulawesi, North Sulawesi and Gorontalo. In 2019 the target for leprosy elimination is in Maluku, North Maluku, North Kalimantan, Papua and West Papua (Kemenkes RI, 2015).

The Indonesian Ministry of Health (2018) stated that there are still some areas in Indonesia that have not eliminated leprosy, meaning that the prevalence of leprosy in the region is still more than 1 per 10,000 population, namely in the eastern part of Java, Sulawesi, Papua, West Papua, Maluku, and Maluku North.

The number of people with leprosy in DKI Jakarta Province in 2017 reached 406 cases. Data collected from the DKI Jakarta Provincial Health Office the number of people with leprosy is at $0.39 \%$, referring to 2017 data with a total of 406 cases. Data from the DKI Jakarta Provincial Health Office show that in West Jakarta there are 108 people with leprosy, East Jakarta with 99 cases, North Jakarta with 94 cases, and South Jakarta with 72 cases, while in Central Jakarta there are 26 cases, and the Thousand Islands 7 cases. (Health Department, 2017). The Central Statistics Agency (BPS) DKI Jakarta throughout 2018 the number of leprosy cases reached 367 cases, namely 131 East Jakarta residents infected with leprosy, the second place was occupied by West Jakarta with a total of 99 cases, Maria's research (2009), determined that factors related to The incidence of leprosy are age, gender, personal hygiene. 
Kora's research (2011), concluded that there is a relationship between gender and the incidence of leprosy in the working area of the Puskesmas Saumlaki Kab. Southeast West Maluku. Chronic diseases such as leprosy are known to occur at all ages, but most are young and productive. The incidence of a disease is closely related to age (Depkes RI, 2006). Research conducted by Yudied., et al (2007), states that there is a relationship between people's habits of sleeping together, wearing alternating clothes, alternating bath towels, and defecating in the garden can also trigger the transmission of various diseases that do not rule out the possibility of disease. leprosy.

The Kebon Jeruk District Health Center is an inpatient First Level Health Facility (FKTP) located in Kebon Jeruk District, DKI Jakarta Province. The working area of the Kebon Jeruk District Health Center has 7 villages, namely North Kedoya, South Kedoya, Duri Kepa, Kelapa Dua, Kebon Jeruk, North Sukabumi and South Sukabumi (Kebon Jeruk Health Center, 2018). DKI Jakarta has entered into a province that has eliminated leprosy, which means that there should no longer be a single case in DKI Jakarta but based on data from the Kebon Jeruk Health Center, it turns out that in 2016 there were 5 cases of leprosy per 9,775 population, in 2017 it increased significantly it was found that leprosy cases were found to be 3 times as many as 16 cases per 10,333 population, in 2018 it was still quite high there were as many as 14 cases per 12,846 population, and in 2019 until April there were 7 cases of leprosy per population. 15,197 residents. From the observation that the home environment is not clean, there is still a lot of garbage in the surrounding environment. And from the data on the impact of leprosy patients in the Kebon Jeruk Puskesmas area, it is known that there are residents who experience stiff hands, contractures, and shortened fingers. Therefore, the researcher took a study entitled Determinants of Leprosy Incidence in the Work Area of the Kebon Jeruk Public Health Center Year 2019 (Kebon Community Health Center) Orange, 2019).

\section{METHODS}

This type of quantitative research aims to get an overview by studying the correlation or relationship between the independent variable and the dependent variable. This study uses case-control, namely by identifying the case group and control group, then examined retrospectively where the independent variable and the dependent variable are measured or collected simultaneously or at the same time. The sample required in this study was 90 respondents, with the comparison for cases and controls in this study is 1: 2, which means 30 cases and 60 controls are needed. Data collection sources of information used primary data, namely data by interview method using research questionnaires which include age, gender, and personal hygiene. While secondary data to see the number of respondents affected by leprosy, namely health profile data and medical record data obtained from the Kebon Jeruk Public Health Center. Furthermore, univariate data analysis was carried out for each variable, while bivariate analysis was carried out using the chi-square test using the SPSS program with a significant level of $\mathrm{p}=0.05(\mathrm{CI}=95 \%)$. 


\section{RESULTS AND DISCUSSION}

Table 1. An overview of each variable in the Work Area of the Kebon Jeruk Health Center in 2019

\begin{tabular}{lcc}
\hline \multicolumn{1}{r}{ Variable } & Frequency (n) & Percentage (\%) \\
\hline Leprosy Incident & 30 & 66.7 \\
Suffer & 60 & 33.3 \\
Not Suffer & & \\
\hline Age & 49 & 54.4 \\
at risk & 41 & 45.6 \\
No Risk & & \\
Gender & 52 & 57.8 \\
Man & 38 & 42.2 \\
Woman & & \\
Personal Hygiene & 48 & 53.3 \\
at risk & 42 & 46.7 \\
No Risk & &
\end{tabular}

\section{Description of Leprosy Incidence in the Work Area of the Kebon Jeruk Health Center in 2019}

Based on the results of the study, it can be seen that from a total of 90 respondents, the proportion who suffer from leprosy is 30 respondents $(66.7 \%)$ and those who do not suffer from leprosy are 60 respondents $(33.3 \%)$.

\section{Age Description in the Work Area of the Kebon Jeruk Health Center in 2019}

Based on the results of the study, it can be seen that from a total of 90 respondents, the results of the proportion of age at risk were 49 respondents $(54.4 \%)$ and the age is not at risk as many as 41 respondents $(45.6 \%)$.

\section{Overview of Gender in the Work Area of the Kebon Jeruk Health Center in 2019}

Based on the results of the study, it can be seen that from a total of 90 respondents, the results of the sex at risk were male with a proportion of 52 respondents $(57.8 \%)$ and the proportion of female sex as many as 38 respondents $(42.2 \%)$.

\section{Overview of Personal Hygiene in the Kebon Jeruk Public Health Center Working Area in 2019}

Based on the results of the study, it can be seen that from a total of 90 respondents, the results of the proportion of personal hygiene at risk are: as many as 48 respondents (53.3\%) and personal hygiene who are not at risk as many as 42 respondents $(46.7 \%)$.

\section{Relationship between Age and Leprosy Incidence in the Work Area of the Kebon Jeruk Health} Center in 2019

Based on the table above, it can be seen that the highest proportion found in the group of people with 
leprosy are respondents at risk at the age of 43 years, namely as many as 25 respondents with a percentage of $83.3 \%$. While the highest proportion in the group not suffering from leprosy is respondents who are not at risk at the age of $<43$ years, namely 36 respondents with a percentage of $60 \%$.

\section{The Relationship between Sex and the Incidence of Leprosy in the Work Area of the Kebon Jeruk Health Center in 2019}

Based on the table above, it can be seen that the highest proportion in the group of male leprosy patients was 18 respondents with a percentage of 60\%. While the lowest proportion in the non-leprosy group was female as many as 26 respondents with a percentage of $43.3 \%$.

From the table above, it can be seen that based on the Chi-Square statistical test where the pvalue read is the continuity correction value because all cells from the $2 \times 2$ table and the expected count value are $>5$ and the $p$-value is 0.940 with a value of $=0.05$. Based on these results, the $p$-value $>0.05$ so it can be concluded that there is no significant relationship between the sex variable and the incidence of leprosy. Meanwhile, the value of the OR (Odds Ratio) for the sex variable is 1.146, which means that the male sex has a 1-time chance of being a preventive or protective factor against leprosy.

From the table above, it is known that based on the Chi-Square statistical test where the p-value read is the continuity correction value because all cells from the table are $2 \times 2$ and the expected count value is $>5$ and the $p$-value is $=0.000$ with $=0.05$. Based on these results, the $p$-value $<0.05$ so it can be concluded that there is a significant relationship between the age variable and the incidence of leprosy. Meanwhile, the OR (Odds Ratio) of the age variable is 7,500 (2,521-22,313) which means that respondents who are 43 years old are at risk of developing leprosy 7.5 times compared to people aged < 43 years. Relationship of Personal Hygiene with Leprosy Incidence in the Work Area of the Kebon Jeruk Health Center in 2019

Based on the results of the table above, it can be seen that the highest proportion is found in the group of people with leprosy at risk are respondents who have poor personal hygiene of 30 respondents with a percentage of $100 \%$. While the highest proportion in the non-leprosy group at risk were respondents who had poor personal hygiene as many as 18 respondents with a percentage of $30 \%$.

From the table above, it can be seen that based on the Chi-Square statistical test where the p-value read is the continuity correction value because all cells from the table are $2 \times 2$ and the expected count value is $>5$ and the p-value is 0.000 with a value of $=0.05$. Based on these results, the p-value $<0.05$ so it can be concluded that there is a significant relationship between personal hygiene variables and the incidence of leprosy.

Research results in southern India adulthood are caused by re-infection or superinfection in individuals who have previously been infected and have which is an endemic area of leprosy, shows that the highest prevalence occurs in the age range of 10-14 years and 30-60 years. There are 2 possibilities for this, first, the incubation period is very long so that leprosy manifestations can only be seen after 
adulthood, and second, the appearance of leprosy in adults. the decline in immunity (immunity) as they grow older. Different results occurred on the island of Nauru which showed that leprosy patients were found in all age groups in relatively equal numbers. These findings further strengthen the notion that leprosy has a fairly variable incubation period and The factor that determines the age distribution of leprosy patients is caused by the length of exposure rather than age itself (Noorden, 1994).

According to WHO, human age is broadly divided into 3 stages, namely children (1-11 years), adolescents (12-16 years), and adults (above 16 years). Leprosy can affect all ages, ranging from infants to old age ( 3 weeks to more than 70 years), but most are young and productive. Productive age is the age when a person has a higher relationship or activity than the unproductive age. This also allows productive age to be more prone to contracting leprosy. Leprosy affects everyone, men are more affected than women with a ratio of 2:1. Likewise, as stated in the Indonesian Ministry of Health (2007), that men are more affected than women. The relatively low incidence of leprosy in women may be due to environmental or biological factors. Like most other infectious diseases, men are more exposed to risk factors as a result of their lifestyle regarding men and women. The incidence of leprosy increases with increasing age. This is caused by the very long incubation period of leprosy and the clinical picture of leprosy appears late. Another possibility is that leprosy in adulthood is caused by reinfection in individuals who have previously been infected and experience decreased immunity when growing up (Noorden, 1994). Leprosy is known to occur at all ages ranging from infants to the elderly or in other words leprosy can attack from the age of three weeks to the age of more than 70 years. but the most leprosy sufferers are in the productive age (Kemenkes RI, 2012). Based on the description above, leprosy can attack at all ages, especially those at risk. Based on research results it can be seen that from 90 respondents in the study, the highest proportion was obtained, namely the age at risk 43 years as much as 49 respondents with a percentage of $54.4 \%$. That the risk age group is 43 years.

Based on the results that have been carried out at the Kebon Jeruk Public Health Center, it was found that respondents with more adult ages than children or older, because based on the results of the study showed that the environment there was dense, humid, trash bins were still not found and slums plus the adults there for bathing habits have not all done it $2 \mathrm{x}$ a day. Thus, the recommendations given to respondents who are older than the age at risk are to take better care of their personal hygiene because usually, those at risk will be more susceptible to being at risk for all kinds of diseases including leprosy.

The Ministry of Health (2007), states that men are more affected than women. The relatively low incidence of leprosy in women may be due to environmental or biological factors. Like most other infectious diseases, men are more exposed to risk factors as a result of their lifestyle. Leprosy affects everyone. Men are more affected than women, with a ratio of 2:1. Although some areas show almost the same incidence, there are even areas that show more women. Leprosy can affect both men and women. According to the records of most countries in the world except in a few countries in Africa, it shows that men are more affected than women (Harahap, 2010). Men suffer from leprosy more because men tend to 
be more active outside the home so that the possibility of contracting leprosy is greater than women (Darmaputra, 2009). The tendency to not wear clothes in everyday life in men is believed to increase the possibility of contracting leprosy through skin contact (Noorden, SK 1994). The gender perspective is recognized as very important in its role in social relations and the development of health practices for men and women. Women have very different needs. Leprosy in this case produces different manifestations between men and women. Based on the results of the study, the incidence of leprosy was more common in gender, namely $68.8 \%$, this is much different from women only $39.2 \%$. Peter, et.al (2002) states that there are differences in the number of people with leprosy between men and women. Leprosy is more common in men than women with a ratio of $2: 1$ each, transmission in men is related to activities carried out every day.

In this study, the case group (who suffered from leprosy) was mostly experienced by male respondents while the control group who did not suffer from leprosy) tended to be dominated by female respondents. The results of this study stated that there was no relationship between gender and the incidence of leprosy. With this, it can be concluded that the male sex factor is more at risk for leprosy than women. This is probably because men work outside the home more often than women, thereby increasing the risk of contracting leprosy, but it is also influenced by the work environment and circumstances. socioeconomic status of the patient.

Personal hygiene is a preventive measure that concerns the individual's responsibility to improve health and limit the spread of infectious diseases, especially those transmitted by direct contact (Noor, 2006). According to the results of research Yudid (2008) stated that personal hygiene includes the habit of sleeping together, wearing alternating clothes, bathing towels used alternately, and defecating in the garden in the community causing the transmission of leprosy.

Based on the results of the study, it can be concluded that most of the respondents' personal hygiene or personal hygiene has not met the requirements, this is because respondents have the habit of bathing less than 2 times a day and they also have the habit of exchanging clothes, using towels alternately, sharing toothbrushes, using bar soap alternately, and rarely changing bed linen. With this, it can be concluded that the male sex factor who has poor personal hygiene is more at risk for leprosy. Based on the description above, personal hygiene which includes bathing habits, the habit of borrowing towels, and exchanging clothes between other members is one of the risk factors. Therefore, people are expected to wear long clothes to minimize skin contact with patients and be more concerned about personal and environmental hygiene, maintain personal hygiene by bathing at least 2 times a day.

From the results of the questionnaire conducted at the Kebon Jeruk Public Health Center, it can be concluded that most of the respondents' hygiene did not meet the requirements, this was because 36 respondents (40\%) who had a habit of bathing less than 2 times a day were found to be 36 . people (40\%) and they also have a habit of borrowing towels as many as 34 people (37.8\%) and exchanging clothes between other members as many as 33 (36.7\%). In addition, individual hygiene is closely related to 
community hygiene and influences each other reciprocally. Poor personal hygiene is a reflection of environmental conditions and unhealthy individual behavior. Personal hygiene in the Kebon Jeruk Public Health Center area is at risk for leprosy events based on observations of the dense environment, think that what they are doing is good.

The efforts made are PHBS (Clean and Healthy Living Behavior) counseling and monitoring and supervision of leprosy around the Kebon Jeruk Health Center to prevent the emergence of new cases of leprosy.

\section{CONCLUSION AND SUGGESTION}

The results of this study indicate that there is a relationship between age and personal hygiene, but there is no relationship between gender and the incidence of leprosy in the Kebon Jeruk Public Health Center Work Area in 2019. Based on the results of the research, the researcher provides suggestions for respondents Those who are at risky ages should take better care of their personal hygiene because they will usually be more susceptible to being at risk of all kinds of diseases. And it is recommended to reduce the risk of leprosy transmission by wearing long clothes, avoiding the use of towels together, taking minimal baths 2 times a day, and avoid the habit of using clothes alternately with others.

\section{REFERENCES}

Adam Sjamsunir. (1978). Personal Hygiene. Jakarta: Bhrata Karya Aksara.

Amiruddin. MD (2003). Leprosy Science. Makassar: Hasanuddin University Press.

Apriani, DN, Rismayanti, \& Wahiduddin. (2018). Risk Factors for Leprosy in Makassar City Risk Factors for Leprosy Disease in Makassar Dwi Ningrum Apriani, Rismayanti, Wahiduddin Epidemiology Section, Faculty of Public Health, Hasanuddin University Keyword: Risk factors, leprosy, ma. 1-13.

Baxter, R., Hastings, N., Law, A., \& Glass, E.

J. . (2008). Ministry of Health Strategic Plan 2015-2019. Animal Genetics, 39(5), 561-563.

Bint Ida Umaya. (2017). Regulation of the Minister of Health of the Republic of Indonesia Number 65 of 2017 concerning the Organization and Work Procedure of the Technical Implementing Unit within the Health Research and Development Agency. Nusantara University PGRI Kediri, 01, 17.Retrieved from http://www.albayan.ae

Boasberg, J., The Department of Education, Academy, T., Academy, R., Trakt, SS, Quinot, G., ... SOUTHEASTERN, $\mathrm{H}$.

(2019). Regulation of the Minister of Health of the Republic of Indonesia Number 11 of 2019 concerning Management of Leprosy. Duke Law Journal, 1(1), 1-13.

Ministry of Health of the Republic of Indonesia, 2006, Handbook for the Eradication of Leprosy. Print XV, Jakarta: Director General of PPM and PL.

Indonesian Ministry of Health. (2007). National Leprosy Control Guidelines. Jakarta: Directorate General of Disease Control and Environmental Health, Ministry of Health, Republic of Indonesia.

Hastings. (1985). leprosy. Edinburgh, London: Churchill Livingstone, Edinburgh.

Hastono, SP (2016). Data Analysis in the Health Sector. Jakarta: Rajawali Press.

Hastono, SP, \& Sabri, L. (2010). Health Statistics. Jakarta: Rajawali Press. 
E-ISSN: $2808-5361$

http://e-journal.fkmumj.ac.id/
Proceeding The First

Muhammadiyah

Internasional- Public Health and Medicine Conference

Ministry of Health. (2015). Leprosy. Jakarta: Data and Information Center of the Indonesian Ministry of Health.

Indonesian Ministry of Health. (2018). Eliminate Stigma and Discrimination Against Leprosy (pp. 1-9). pp. 1-9.

https://doi.org/http://dx.doi.org/10.1213/0 1.ANE.0000403381.51061.df

Indonesian Ministry of Health. (1999). Housing Health Regulations (pp. 1-6). pp. 1-6.

Health, K., Indonesia, R., Stunting, P., \& Siswanto, K. (2018). Rakerkesnas 2018, the Ministry of Health hastened to address 3 health problems. 2017-2018.

Maria Christina, 2008, Risk Factor Analysis of Leprosy Incidence (Case Study at Leprosy Hospital Donorejo Jepara) 2008. Thesis: Semarang State University

Marwali Harahap, 2000, Dermatology, Jakarta: Hippocrates

Mukono, HJ (2000). Basic Principles of Environmental Health. Surabaya: Airlangga University Press.

Notoatmodjo, S. (2007). Health Promotion and Behavioral Science. Jakarta: Rineka Cipta.

Notoatmodjo, S. (2010). Health Promotion: Theory and Application. Jakarta: Rineka Cipta.

Parsiyo. (2013). Indicators of Development Success. 1-20.

Perry and Potter, 2006. Fundamentals of Nursing. Edition 4. Jakarta: EGC. Banten Province Health Profile 2012. Banten Health Office.

Peter. ES, et al. 2002. Male-Female (Sex) Differences in Leprosy Patients in South-Eastern Nigeria:

Female Present Late for Diagnosis and Treatment and Have Higher Rates of Deformity.73:262267.

Prawoto, 2008, Risk Factors Affecting the Occurrence of Leprosy Reaction Thesis: Diponegoro University Semarang.

Sastroasmoro, S. (2014). Fundamentals of Clinical Research Methodology. Jakarta: Sagung Seto.

Sugiyono. (2012). Quantitative, Qualitative, and Combination Research Methods (Mixed Methods). Bandung: Alphabeta.

Sampang, DIK (2014). Lack of counseling and passive case finding affect the incidence of level II leprosy disability in Sampang district. 290-303.

Tarwoto, Wartonah. 2006. Human Basic Nursing and Nursing Process. Jakarta : Salemba Medika

Yudied et al. 2008. Study of Control of Potential Risk Factors for Leprosy Transmission and Interventions at Pragaam Health Center, Sumenep Regency in 2007. Human Media Bulletin Volume 03 Number 03 September 2008.

Widiyanto, MA (2013). Application Statistics: Concepts \& Applications of SPSS/LISREL in Educational Research, Psychology \& Other Social Sciences. Jakarta: PT Elex Media Komputi 